\title{
Adsorption of colour, TSS and COD from palm oil mill effluent (POME) using acid-washed coconut shell activated carbon: Kinetic and mechanism studies
}

\author{
Yong Yin Sia, Ivy Ai Wei Tan ${ }^{\mathrm{a}}$ and Mohammad Omar Abdullah \\ Department of Chemical Engineering and Energy Sustainability, Faculty of Engineering, Universiti Malaysia Sarawak, 94300 Kota \\ Samarahan, Malaysia
}

\begin{abstract}
The disposal of palm oil mill effluent (POME) without proper treatment before being discharged into natural water sources has become undesirable because of high concentration of suspended solid (SS), oil and grease $(O \& G)$, chemical oxygen demand (COD) and biological oxygen demand (BOD). This study investigated the feasibility of removing colour, total suspended solid (TSS) and COD using acid-washed coconut shell based activated carbon (CSAC) through the evaluation of the adsorption uptake as well as the adsorption kinetics and mechanism. The percentage removal of colour, TSS and COD from POME onto CSAC were $61 \%, 39 \%, 66 \%$, respectively achieved within 48 hours of contact time. The kinetic models studied were pseudo-first-order (PFO), pseudo-secondorder (PSO), and Elovich models. The intra-particle diffusion (IPD) model was studied to interpret the adsorption diffusion mechanism. The adsorption of colour, TSS and COD onto CSAC were best interpreted by the PSO model, and well fitted by the Elovich model. The IPD and Boyd plots indicated that IPD and film diffusion controlled the adsorption of colour, TSS and COD onto the CSAC.
\end{abstract}

\section{Introduction}

Palm oil industry is a main economic contributor in Malaysia. Palm oil mill effluent (POME) is the largest waste contributor in the palm oil mills. Oil palm waste is also generated from the refined fresh fruit bunch (FFB). FFB consists of $30 \%$ fibre, $6 \%$ shell, 3\% decanter cake and $28.5 \%$ empty fruit bunch (EFB). In Malaysia, approximately 30 million tonnes of POME were released by 381 palm oil production mills in 2004 [1]. Malaysia produced at least 44 million tonnes of POME in 2008 [2]. An efficient and sustainable management system is therefore required for treatment of POME to protect the environment and monitor the degradation of river water in order to prevent environmental pollution [1].

In Malaysia, ponding system has been applied in most palm oil production mills to treat POME [3]. This is mainly because Malaysia has large areas of land for the ponding system. The ponding system is more economically feasible and can stand a larger limit of organic loading rate (OLR) [4]. However, large amounts of methane $\left(\mathrm{CH}_{4}\right)$ and carbon dioxide $\left(\mathrm{CO}_{2}\right)$ are released in an uncontrollable manner from open ponds into the atmosphere. This might worsen the global warming effect as $6.54 \mathrm{~kg} \mathrm{CH} /$ tonne $\mathrm{FFB}$ would be emitted from the ponds [5]. The equivalent amount of $\mathrm{CO}_{2}$ released into the air is $137.4 \mathrm{~kg}$. In 2020, POME treatment ponds are estimated to release 0.36 million tonnes of $\mathrm{CH}_{4}$ [6]. $\mathrm{CH}_{4}$ has approximately 20 times more greenhouse effect than

\footnotetext{
a Corresponding author: awitan@unimas.my
}

$\mathrm{CO}_{2}$ with a possible 100 year global warming effect [7] Therefore, by the year of 2020, the ponding systems in Malaysia would cause greenhouse effect corresponding to 7.2 million tonnes $\mathrm{CO}_{2}$

Activated carbon (AC) has been proven to be efficient in treating various wastewaters. Nevertheless, its constraint is the high cost of commercial AC. Therefore, derivation of $\mathrm{AC}$ from agriculture wastes has been emphasized in recent years since the interest in low-cost $\mathrm{AC}$ derived from renewable raw materials is growing. A past study reported that the removal efficiency of suspended solids and turbidity was $89.1 \%$ and $91.4 \%$, which was respectively achieved by utilizing powdered activated carbon (PAC) obtained from EFB, with the following specific conditions: $3.5 \mathrm{~g}$ PAC/100 mL biotreated POME, contact time of 45 minutes and mixing speed of $150 \mathrm{rpm}$ [8]. Another study on column adsorption of dye wastewater was conducted with a bottom layer of granular activated carbon (GAC) and an upper layer of zeolite in a column of $6.35 \mathrm{~cm}$ diameter at $2.84 \mathrm{~mL} / \mathrm{cm}^{2}$.min surface loading rate and $10 \mathrm{~cm}$ bed height [9]. The reduction of chemical oxygen demand (COD), ammonia and colour were $59.46 \%, 60.82 \%$ and $58.4 \%$, respectively. A study on colour adsorption from biologically treated POME by utilizing AC derived from palm kernel shell which was produced by following chemical and microwave method (PKSCM) reported colour removal of $100 \%$ at the optimum condition of $5 \mathrm{~g}$ $\mathrm{AC} / 100 \mathrm{~mL}$ POME, $\mathrm{pH} 2$, and equilibrium time of 12 
hours [10]. Therefore, the aim of this study is to investigate the feasibility of acid-washed CSAC to remove colour, TSS and COD from POME through evaluation of the adsorption uptake, kinetics and mechanism.

\section{Materials and methods}

\subsection{Materials}

The POME sample was obtained from the second anaerobic pond of a palm oil mill located at Kota Samarahan, Sarawak, Malaysia. The POME sample was kept in a refrigerator at $4^{\circ} \mathrm{C}$. CSAC with mesh size $8 \times 30$ and iodine number 1000 was used as the adsorbent to treat POME. Distilled water was utilized for the solutions and reagents preparation.

\subsection{Batch adsorption studies}

In the batch adsorption study, $5 \mathrm{~g}$ CSAC was added to $100 \mathrm{~mL}$ POME solution in $250 \mathrm{~mL}$ closed flask. The sample was stirred at $150 \mathrm{rpm}$ utilizing a rotary orbital shaker over a time duration ranging from 15 minutes to 48 hours at room temperature. For kinetic studies, samples were withdrawn at certain regular times using a glass pipette. The adsorbed quantity of colour, TSS and COD, $q_{t}(\mathrm{mg} / \mathrm{g})$ at time $t$ and $q_{e}(\mathrm{mg} / \mathrm{g})$ at equilibrium stage were determined through Eq. (1) and Eq. (2), respectively:

$$
\begin{gathered}
q_{t}=\frac{\left(C_{0}-C_{t}\right) V}{M} \\
q_{e}=\frac{\left(C_{0}-C_{e}\right) V}{M}
\end{gathered}
$$

where $C_{0}, C_{t}$ and $C_{e}(\mathrm{mg} / \mathrm{L})$ are the POME concentrations at initial, certain time interval and equilibrium stage, respectively. $V$ is the POME volume (L) and $M$ is CSAC mass $(\mathrm{g})$.

\subsection{Adsorption kinetic studies}

\subsubsection{Kinetic model: Pseudo-first-order}

The pseudo-first-order (PFO) kinetic model is defined according to Eq. (3) [11], which can be shown as a linear expression by Eq. (4) through integration over boundary conditions such as the colour, TSS and COD adsorbed quantity $q=0$ at $t=0$ and $q=q_{e}$ at $t=t$.

$$
\begin{gathered}
\frac{d q}{d t}=k_{1}\left(q_{e}-q\right) \\
\ln \left(q_{e}-q_{t}\right)=\ln q_{e}-k_{1} t
\end{gathered}
$$

where $q_{t}$ and $q_{e}(\mathrm{mg} / \mathrm{g})$ are the adsorbed quantities of adsorbate at any time, $t(\mathrm{~h})$ and equilibrium phase. $k_{l}\left(\mathrm{~h}^{-1}\right)$ is the constant of adsorption rate. $k_{l}$, and $\ln q_{e}$ are obtained from the slope and intercept of the graph of $\ln \left(q_{e}-q_{t}\right)$ versus $t$.

\subsubsection{Kinetic model: Pseudo-second-order}

According to Ho et al. [12], the pseudo-second-order (PSO) kinetic model is expressed as Eq. (5). The Eq. (5) can be expressed as Eq. (6) by separating the variables. Further integrating Eq. (6) over boundaries $q=0$ at $t=0$ and $q=q_{e}$ at $t=t$, Eq. (6) turns into Eq. (7) in which $k_{2}$ $(\mathrm{g} / \mathrm{mg} \mathrm{h})$ is the second-order adsorption rate constant.

$$
\begin{gathered}
\frac{d q}{d t}=k_{2}\left(q_{e}-q\right)^{2} \\
\frac{d q}{\left(q_{e}-q\right)^{2}}=k_{2} d t \\
\frac{t}{q_{t}}=\frac{1}{k_{2} q_{e}^{2}}+\frac{1}{q_{e}} t
\end{gathered}
$$

The linear graph between $t / q_{t}$ and $t$ provides the slope $1 / q_{e}$ and corresponding intercept $1 / k_{2} q_{e}^{2}$.

\subsubsection{Elovich model}

As expressed by Eq. (8), the Elovich model is defined according to Aharoni et al. [13] in linear form, where $x$ and $y$ are the constants of the Elovich model, which can be obtained from $q_{t}$ versus $\ln t$ graph.

$$
q_{t}=\frac{1}{y} \ln (x y)+\frac{1}{y} \ln t
$$

\subsection{Adsorption mechanism}

Weber and Morries [14] defined the intra-particle diffusion (IPD) model as in Eq. (9).

$$
q_{t}=k_{p i} t^{1 / 2}+C_{i}
$$

where $k_{p i}\left(\mathrm{mg} / \mathrm{g} \mathrm{h}^{1 / 2}\right)$ is the diffusion rate constant of stage $i$, obtained from the graph of $q_{t}$ versus $t^{1 / 2} . C_{i}$ is the thickness of boundary layer. If the intercept value is higher, the boundary layer effect will be greater [15]. The IPD occurs as a result of linear graph. The rate of adsorption is governed by the IPD if the straight line intersects with the origin point. On the contrary, IPD occurs together with some other mechanisms [16].

The actual slow step involved can be estimated by employing the Boyd model as expressed in Eq. (10) and Eq. (11).

$$
\begin{gathered}
B=1-\left(6 / \pi^{2}\right) \exp \left(-F_{t}\right) \\
B=\frac{q_{t}}{q_{0}}
\end{gathered}
$$

where $q_{0}(\mathrm{mg} / \mathrm{g})$ is the adsorbed adsorbate quantity at infinite time and $q_{t}(\mathrm{mg} / \mathrm{g})$ is the adsorbed adsorbate quantity at any time $t(\mathrm{~h}), B$ represents adsorbed solute fraction at any time $t$, and $F_{t}$ is a mathematical function of $B$. Eq. (10) is simplified by substituting Eq. (11) in Eq. (10) and becomes Eq. (12) for $B$ values that are greater than 0.85 . While, for $B$ values that are smaller than 0.85 , Eq. (13) is used to calculate $F_{t}$. 


$$
\begin{gathered}
F_{t}=-0.4977-\ln (1-B) \\
F_{t}=\left(\sqrt{\pi}-\sqrt{\pi-\left(\frac{\pi^{2} B}{3}\right)}\right)^{2}
\end{gathered}
$$

Referring to Boyd's theory, adsorption process has three steps in sequence, namely film diffusion, particle diffusion, and adsorption on the adsorbent inner surface $[17,18]$. The third step cannot be considered as a step that governs the adsorption rate because it is a very fast step. Particle diffusion controls the rate if exterior transport is greater than the inner transport. Film diffusion controls the adsorption rate if exterior transport is lesser than inner transport and the moving of adsorbate molecules to the boundary at a significant rate may not occur if exterior transport is equivalent to that of inner transport.

\subsection{Error analysis}

An error function is required to be determined for evaluating the model suitability to fit the experimental results. Sum of squared errors (SSE, \%) as shown in Eq. (14) is used for analysis of error calculation.

$$
S S E=\sqrt{\frac{\sum\left(q_{e, \exp }-q_{e, c a l}\right)^{2}}{N}}
$$

where $N$ is the number of collected data, $q_{e, e x p}$ and $q_{e, c a l}$ $(\mathrm{mg} / \mathrm{g})$ are equilibrium adsorption capacity values according to the experimental and theoretical results, respectively. The lower the SSE, the better a fit is.

\subsection{Analytical methods}

The POME colour was analysed according to platinumcobalt standard method 8025 at $455 \mathrm{~nm}$ wavelength by utilizing a spectrophotometer (HACH, DR900) [19]. A $10 \mathrm{~mL}$ POME sample was placed in a square quartz sample cell. TSS was determined spectroscopically using the American Public Health Association (APHA) Standard method 8006 through $\mathrm{HACH}$ spectrophotometer (DR900) by placing $10 \mathrm{~mL}$ POME sample in the same sample cell used for colour analysis [19]. COD was determined by APHA Standard method 8000 using spectroscopic method. A COD vial (HR 20-1500 mg/L) was used for adding $2 \mathrm{~mL}$ POME sample. Then, the sample was digested for 2 hours by using a $\mathrm{HACH}$ digester (DRB200). The COD concentration was then measured using a $\mathrm{HACH}$ spectrophotometer [19].

\section{Results and discussion}

\subsection{Effect of POME initial concentration and contact time on colour, TSS and COD adsorption}

Figures 1(a)-(c) show the adsorption uptake of colour, TSS, and COD onto CSAC at various POME initial concentrations and adsorption times. The plots showed that the adsorption of colour, TSS and COD were generally increased over time with reference to POME initial concentrations ranging $50 \%$ to $100 \%$. At the initial stage, the adsorption of colour, TSS, and COD was fast and became slower while approaching equilibrium. The fast adsorption phenomenon could be correlated with the availability of significant number of vacant active surface sites on the CSAC at the beginning process. Over a certain time period, the leftover marginally available vacant surface sites of CSAC had become difficult to be filled up due to significant forces of repulsion present between the pollutants on the CSAC as well as in the POME solution. The amount of colour, TSS and COD adsorbed onto CSAC increased with POME initial concentration. This was because the rising POME initial concentration increased the mass transfer driving force.
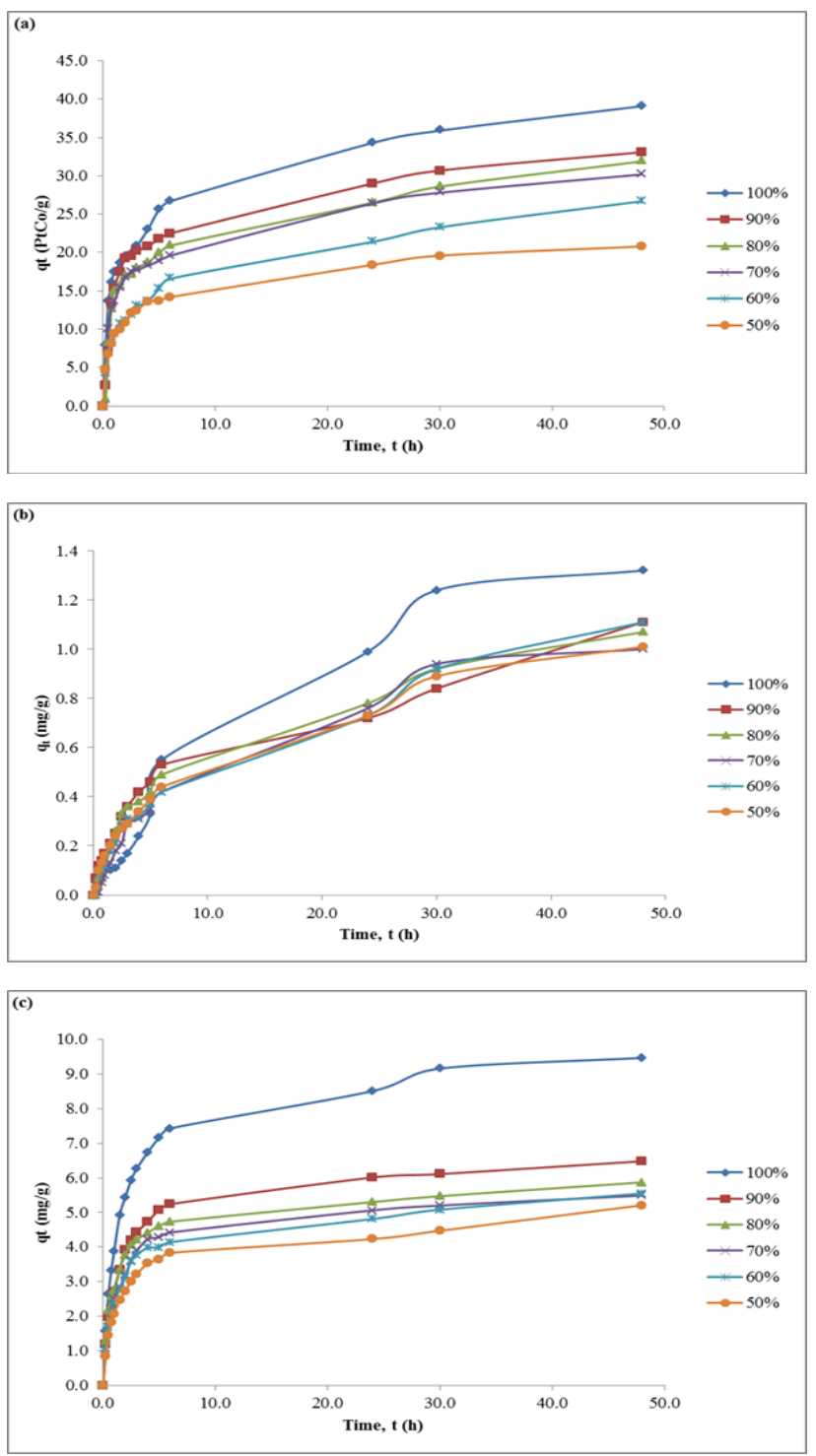

Figure 1. Adsoprtion uptake of (a) colour, (b) TSS, and (c) COD onto CSAC.

The percentage reductions of colour, TSS and COD from POME onto CSAC achieved within 48 hours were $61 \%, 39 \%$ and $66 \%$, respectively as indicated in Figure 2 . 
The operating conditions were $\mathrm{pH} 8$ and $5 \mathrm{~g}$ CSAC/100 $\mathrm{mL}$ POME. In a past study on treatment of biologically treated POME using banana peel activated carbon (BPAC), the reduction efficiency of colour $(95.96 \%)$, TSS (100\%), COD (100\%), BOD (97.41\%), and tannin and lignin $(76.74 \%)$ were reported. These results were obtained at optimized process condition of $\mathrm{pH} 2$, contact time of 30 hours and $30 \mathrm{~g} \mathrm{BPAC} / 100 \mathrm{~mL}$ POME [20]. Another study on treatment of biologically treated POME using commercial AC reported removal efficiency of $28.35 \%, 29.02 \%$, and $65.9 \%$ for colour, TSS and COD, respectively which were achieved using an AC dose of 5 $\mathrm{g} / 100 \mathrm{~mL}$ POME and an equilibrium time of 5 hours [19].

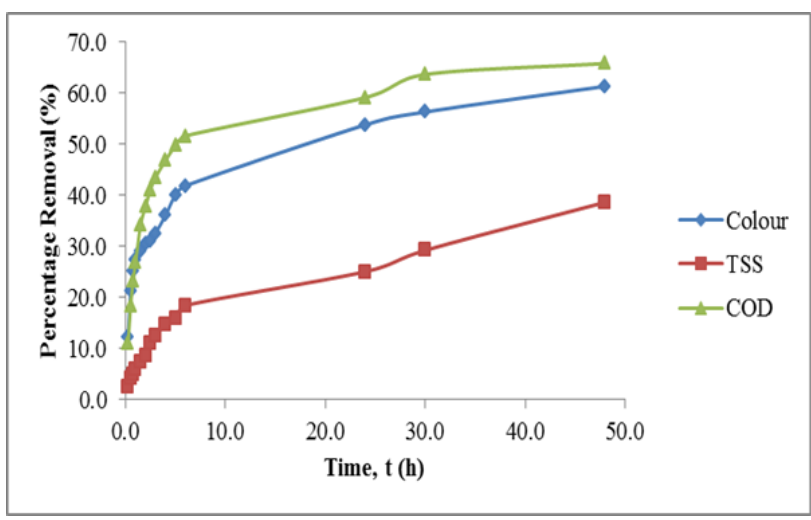

Figure 2. Percentage removal of colour, TSS, and COD from POME onto CSAC.

\subsection{Adsorption kinetics study}

The kinetics study of colour, TSS and COD adsorption onto CSAC as well as experimental data correlation analysis were carried by employing PFO, PSO, and Elovich kinetic models. Table 1 shows the kinetic parameters, correlation coefficients $\left(\mathrm{R}^{2}\right)$ and SSE obtained by using the three models. The $\mathrm{R}^{2}$ and SSE were used to express the agreement between the results as obtained from model analysis and experiments. High $\mathrm{R}^{2}$ and low SSE signified that the kinetic models fitted the adsorption process. For removal of colour and COD, the $\mathrm{R}^{2}$ values of PSO model were higher than the $\mathrm{R}^{2}$ of the other two models. Although the $\mathrm{R}^{2}$ value of the PFO model obtained for adsorption of TSS was higher than the $\mathrm{R}^{2}$ of the other two models, the SSE value of the PFO model was also relatively higher. Therefore, the kinetics of colour, TSS and COD adsorption onto CSAC were better interpreted by the PSO and Elovich models due to the comparable $\mathrm{R}^{2}$ values and SSE values obtained for both models.

Figure 3 shows the comparison of different kinetic model analysis with the experimental results for the adsorption of colour, TSS and COD of POME onto CSAC. The $\mathrm{q}_{\mathrm{e}}$ values calculated by using the PSO and Elovich kinetic models were in accordance with $\mathrm{q}_{\mathrm{e}}$ of experimental results. This indicated a good correlation between the PSO and Elovich kinetic models with respect to adsorption of colour, TSS and COD of POME onto CSAC. The suitability of the PSO kinetic model indicated that the step that controls the adsorption rate was mainly chemical sorption. The PSO kinetic model also indicated that the colour, TSS and COD adsorption rates were affected more by the number of available adsorption sites on the CSAC surface than the effect of POME solution concentration [21]. The adsorption rate was governed by a second-order rate law. The $\mathrm{k}_{2}$, PSO rate constant, for TSS adsorption was higher than that of colour and COD. The Elovich model also indicated chemisorption. The calculated $\mathrm{q}_{\mathrm{e}}$ values from the Elovich model fitted the experimental $\mathrm{q}_{\mathrm{e}}$ values well (Figure 3) which indicated that the colour, TSS and COD adsorption onto CSAC was highly heterogeneous system [22].

In a study on the use of improved EFB-based PAC for the reduction of suspended solids and turbidity from biotreated POME, the adsorption kinetics were also discovered to be better interpreted using the PSO model with $\mathrm{R}^{2}$ value of 0.9998 . This meant the sorption trend was due to the chemisorption [8]. Another study on the reduction of colour, TSS, BOD, COD, and lignin and tannin from biologically treated POME using natural banana peel, methylated banana peel and BPAC also revealed that the adsorption kinetics were governed by the PSO model with $\mathrm{R}^{2}$ values of more than 0.99 and very low relative average errors [20]. Besides, a study on adsorption of colour, TSS and COD from biologically treated POME onto $\mathrm{AC}$ also expressed that the adsorption kinetics fitted the PSO model well with high $\mathrm{R}^{2}$ and low $\chi^{2}$ values. The kinetics of colour, TSS and COD adsorption onto the $\mathrm{AC}$ also fitted the Elovich model with $\mathrm{R}^{2}$ values of $0.9407-0.9968$ and $\chi^{2}$ of $0.054931-1.919106$ [19].

Table 1. Kinetic parameter analysis results using PFO, PSO and Elovich models

\begin{tabular}{|c|c|c|c|c|}
\hline \multicolumn{2}{|c|}{ Variables } & Colour & TSS & COD \\
\hline \multicolumn{2}{|c|}{$\mathrm{q}_{\mathrm{e}, \exp }(\mathrm{mg} / \mathrm{g})$} & 39.1000 & 1.1100 & 9.4700 \\
\hline \multirow{4}{*}{$\begin{array}{l}\text { PFO } \\
\text { model }\end{array}$} & $\begin{array}{r}\mathbf{q}_{\mathrm{e}, \mathrm{cal}} \\
(\mathrm{mg} / \mathrm{g})\end{array}$ & 29.0291 & 1.0542 & 7.4902 \\
\hline & $k_{1}\left(h^{-1}\right)$ & 0.1545 & 0.1026 & 0.2450 \\
\hline & $\mathbf{R}^{2}$ & 0.8600 & 0.9852 & 0.9374 \\
\hline & SSE & 10.4137 & 0.0592 & 2.0270 \\
\hline \multirow{4}{*}{$\begin{array}{l}\text { PSO } \\
\text { model }\end{array}$} & $\begin{array}{r}\mathbf{q}_{\mathrm{e}, \mathrm{cal}} \\
(\mathrm{mg} / \mathrm{g})\end{array}$ & 28.6533 & 0.7775 & 8.8968 \\
\hline & $\begin{array}{r}k_{2}(g / m g \\
h)\end{array}$ & 0.0453 & 0.3799 & 0.0910 \\
\hline & $\mathbf{R}^{2}$ & 0.9845 & 0.9306 & 0.9994 \\
\hline & SSE & 1.4269 & 0.0189 & 0.0571 \\
\hline \multirow{5}{*}{$\begin{array}{c}\text { Elovich } \\
\text { model }\end{array}$} & $\begin{array}{r}\mathbf{q}_{\mathrm{e}, \text { cal }} \\
(\mathrm{mg} / \mathrm{g})\end{array}$ & 36.6072 & 0.7649 & 11.5074 \\
\hline & $\mathbf{x}$ & 119.3950 & 0.5940 & 15.8458 \\
\hline & $\mathbf{y}$ & 0.1912 & 6.9061 & 0.5196 \\
\hline & $\mathbf{R}^{2}$ & 0.9639 & 0.9234 & 0.9962 \\
\hline & SSE & 0.9298 & 0.0383 & 0.1092 \\
\hline
\end{tabular}



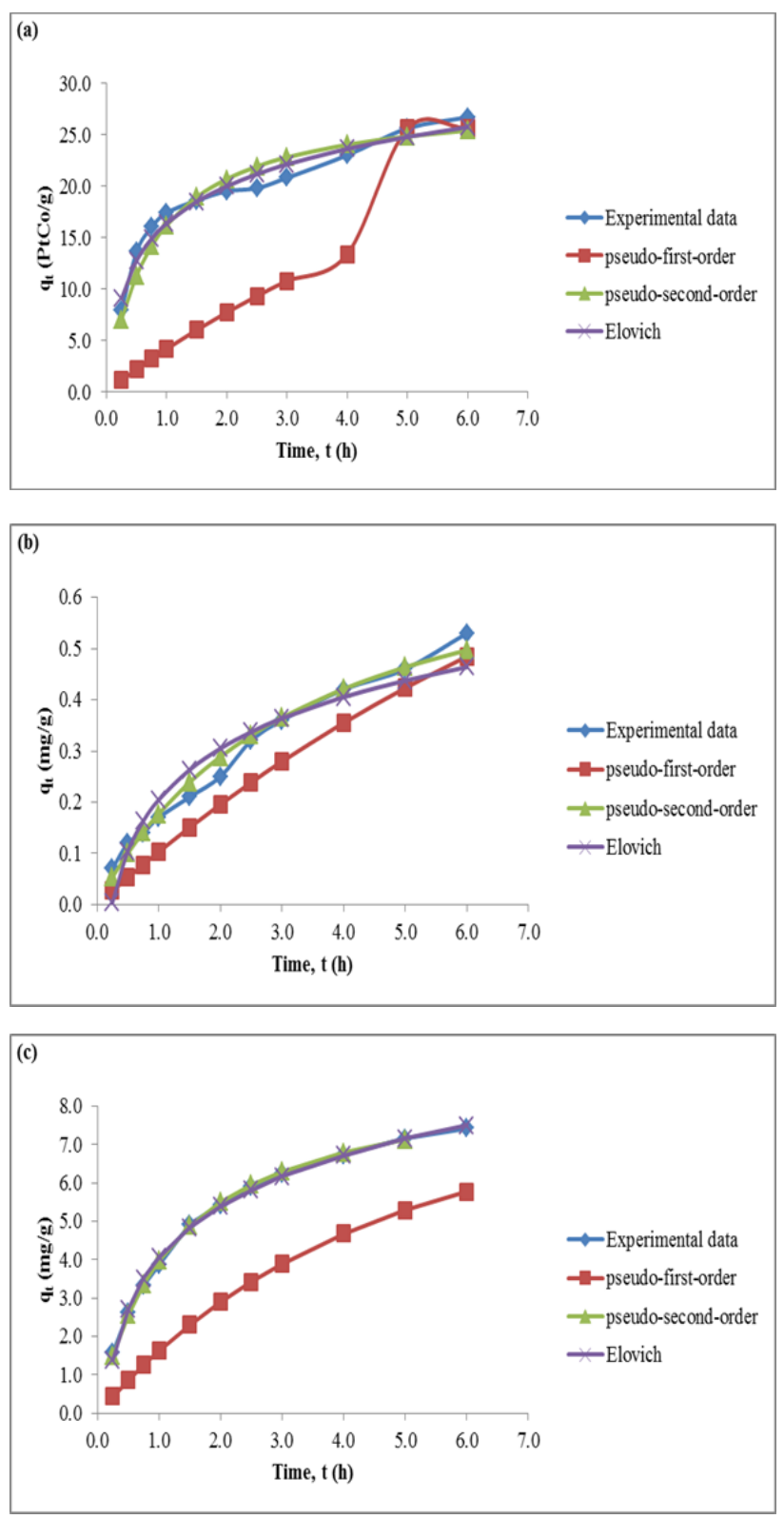

Figure 3. Comparison of different kinetic models with experimental data of (a) colour, (b) TSS, and (c) COD adsorption onto CSAC.

\subsection{Adsorption mechanism}

As shown in Figure 4, outer surface adsorption occurred in the first sharper section [23-25]. The second step described the gradual adsorption for the removal of colour, TSS and COD. The rate controlling of the second section was IPD. The linear lines of the second section as shown in Figure 4(a)-(c) did not intersect the origin due to the difference in the initial and final mass transfer rate of adsorption [23-25]. This implied that the rate of adsorption might be controlled by both IPD and film diffusion [24,26-27]. The actual mechanisms that controlled the adsorption rate were further evaluated through Boyd plots as shown in Figure 5. The linear lines for adsorption of colour, TSS and COD onto CSAC did not intersect with the origin point. This confirmed that the colour, TSS and COD adsorption onto CSAC were controlled by both IPD and film diffusion [24].
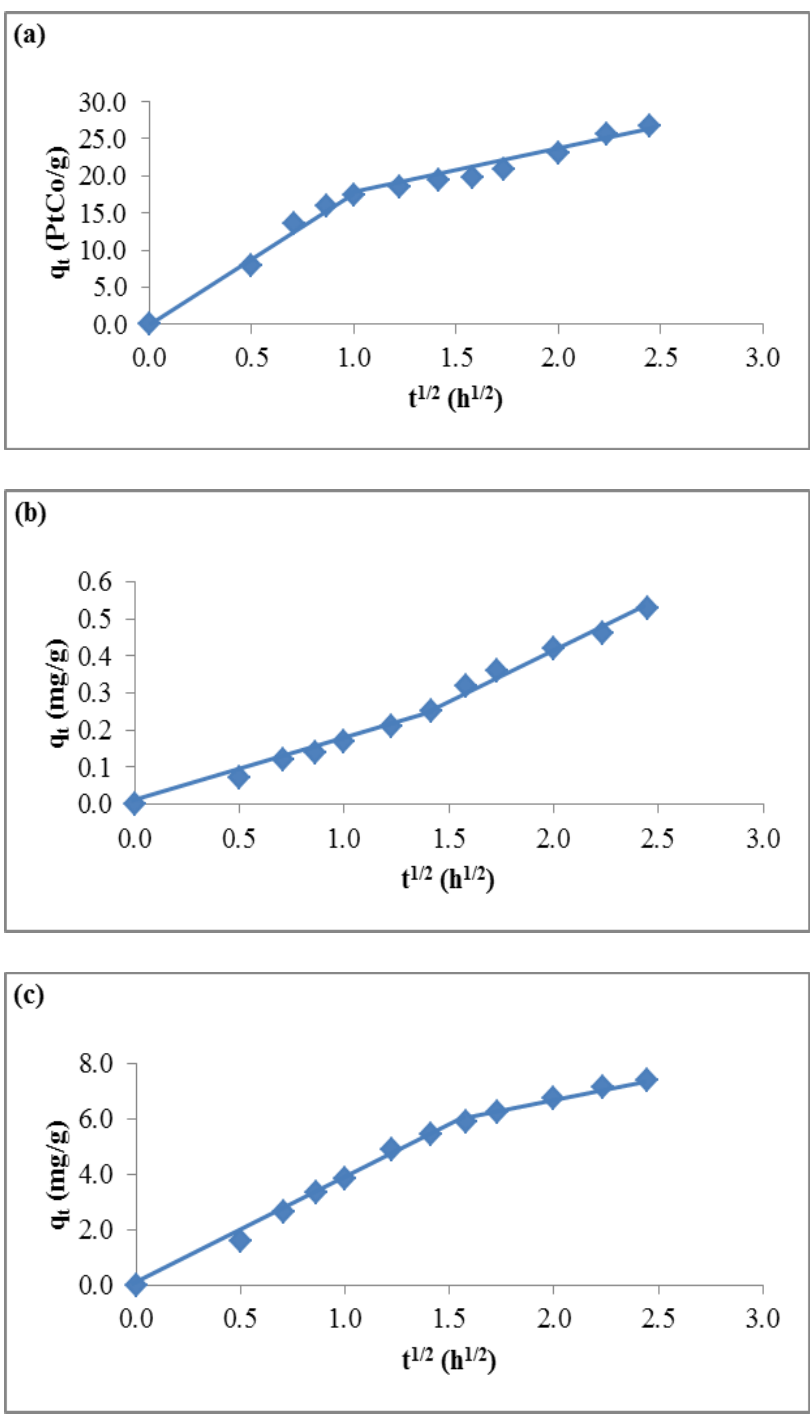

Figure 4. IPD plots of (a) colour, (b) TSS and (c) COD adsorption onto CSAC.

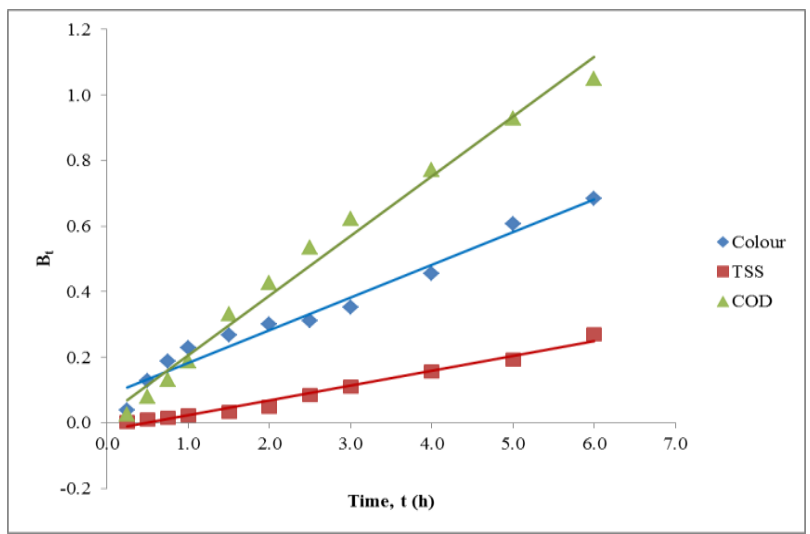

Figure 5. Boyd plots of colour, TSS and COD adsorption onto CSAC. 


\section{Conclusion}

Acid-washed CSAC was successfully used to remove colour, TSS and COD from POME, with percentage removal of $61 \%, 39 \%$ and $66 \%$, respectively. The adsorption kinetics of colour, TSS and COD onto CSAC were best interpreted by the PSO and Elovich models. The fit of the IPD and Boyd models explained that IPD and film diffusion controlled the adsorption of colour, TSS and COD onto CSAC.

\section{Acknowledgements}

The authors acknowledge Universiti Malaysia Sarawak (UNIMAS) for providing research grant F02/SpGS/1406/16/7 under the Special Grant Scheme and the Ministry of Higher Education Malaysia (MOHE) for providing financial support under MyBrain15.

\section{References}

1. J.D. Bala, J. Lalung, N. Ismail, Palm oil mill effluent (POME) treatment "microbial communities in an anaerobic digester": A review, IJSRP 4 (6) (2014) $1-24$.

2. T.Y. Wu, A.W. Mohammad, J.Md. Jahim, N. Anuar, Pollution control technologies for the treatment of palm oil mill effluent (POME) through end-of-pipe processes, J. Environ. Manage. 91 (7) (2010) 1467-1490.

3. A.N. Ma, A.S.H. Ong, Pollution control in palm oil mills in Malaysia, J. Am. Oil Chem. Soc. 62 (2) (1985) 261-266.

4. P.E. Poh, M.F. Chong, Development of anaerobic digestion methods for palm oil mill effluent (POME) treatment, Bioresour. Technol. 100 (1) (2009) 1-9.

5. F. Schuchardt, K. Wulfert, Darnoko, T. Herawan, Effect of new palm oil mill processes on the EFB and POME utilization, Journal of Oil Palm Research Special Issue (2008) 115-126.

6. Y. Shirai, M. Wakisaka, S. Yacob, M.A. Hassan, S. Suzuki, Reduction of methane released from palm oil mill lagoon in Malaysia and its countermeasures, Mitig. Adapt. Strategies Glob. Chang. 8 (3) (2003) 237-252.

7. L. Milich, The role of methane in global warming: Where might mitigation strategies be focused, Glob. Environ. Chang. 9 (3) (1999) 179-201.

8. M.K. Amosa, M.S. Jami, M.F.R. Alkhatib, T. Tajari, D.N. Jimat, R. U. Owolabi, Turbidity and suspended solids removal from high-strength wastewater using high surface area adsorbent: Mechanistic pathway and statistical analysis, Cogent Eng. 3 (1) (2016) 1-18.

9. S. Syafalni, A. Ismail, I. Dahlan, K.W. Chan, Treatment of dye wastewater using granular activated carbon and zeolite filter, Modern Applied Science 6 (2) (2012) 37-51.

10. R.R. Mohammed, Decolorisation of biologically treated palm oil mill effluent (POME) using adsorption technique, IRJES 2 (10) (2013) 1-11.
11. S. Langergren, B.K. Svenska, Zur theorie der sogenannten adsorption geloester stoffe, Veternskapsakad Handlingar 24 (4) (1898) 1-39.

12. Y.S. Ho, G. McKay, The kinetics of sorption of basic dyes from aqueous solutions by sphagnum moss peat, Can. J. Chem. Eng. 76 (1998) 822-826.

13. C. Aharoni, F.C. Tompkins, in: D.D. Eley, H. Pines, P.B. Weisz (Eds.), Advances in Catalysis and Related Subjects vol. 21 (Academic Press, New York, 1970).

14. W.J. Weber, J.C. Morris, Proc. Int. Conf. Water pollution symposium vol.2, pp.231-266 (Pergamon, Oxford, 1962).

15. D. Kavitha, C. Namasivayam, Experimental and kinetic studies on methylene blue adsorption by coir pith carbon, Bioresour. Technol. 98 (2007) 14-21.

16. H.K. Boparai, M. Joseph, D.M. O'Carroll, Kinetics and thermodynamics of cadmium ion removal by adsorption onto nanozerovalent iron particles, J. Hazard. Mater. 186 (2011) 458-465.

17. G.E. Boyd, A.W. Adamson, L.S. Meyers, The exchange adsorption of ions from aqueous solution by organic zeolites. II. Kinetics, J. Am. Chem. Soc. 69 (1947) 2836-2848.

18. D. Reichenberg, Properties of ion exchange resins in relation to their structure. III. Kinetics of exchange, J. Am. Chem. Soc. 75 (1953) 589-597.

19. R.R. Mohammed, M.R. Ketabchi, G. McKay, Combined magnetic field and adsorption process for treatment of biologically treated palm oil mill effluent (POME), Chem. Eng. J. 243 (2014) 31-42.

20. R.R. Mohammed, M.F. Chong, Treatment and decolorization of biologically treated Palm Oil Mill Effluent (POME) using banana peel as novel biosorbent, J. Environ. Manage. 132 (2014) $237-$ 249.

21. J. Gao, D. Kong, Y. Wang, J. Wu, S. Sun, P. Xu, Production of mesoporous activated carbon from tea fruit peel residues and its evaluation of methylene blue removal from aqueous solutions, BioResour. 8 (2013) 2145-2160.

22. Y.S. Ho, G. McKay, Application of kinetic models to the sorption of copper (II) on to peat, Adsorpt. Sci. Technol. 20 (2002) 797-815.

23. R. M. Ali, H. A. Hamad, M. M. Hussein, G. F. Malash, Potential of using green adsorbent of heavy metal removal from aqueous solutions: Adsorption kinetics, isotherm, thermodynamic, mechanism and economic analysis, Ecol. Eng. 91 (2016) 317-332.

24. H. Wang, X. Yuan, Y. Wu, G. Zeng, H. Dong, X. Chen, L. Leng. Z. Wu, L. Peng, In situ synthesis of $\mathrm{In}_{2} \mathrm{~S}_{3} @ M I L-125(\mathrm{Ti})$ core-shell microparticle for the removal of tetracycline from wastewater by integrated adsorption and visible-light-driven photocatalysis, Appl. Catal., B: Environ. 186 (2016) 19-29.

25. T. Anitha, P. S. Kumar, K. S. Kumar, B. Ramkumar, S. Ramaligam, Adsorptive removal of $\mathrm{Pb}(\mathrm{II})$ ions from polluted water by newly synthesized chitosan-polyacrylonitrile blend: Equilibrium, kinetic, mechanism and 
thermodynamic approach, Process Saf. Environ. Prot. 98 (2015) 187-197.

26. S. Duan, R. Tang, Z. Xue, X. Zhang, Y. Zhao, W. Zhang, J. Zhang, B. Wang, S. Zeng, D. Sun, Effective removal of $\mathrm{Pb}(\mathrm{II})$ using magnetic $\mathrm{Co}_{0.6} \mathrm{Fe}_{2.4} \mathrm{O}_{4}$ micro-particles as the adsorbent: Synthesis and study on the kinetic and thermodynamic behaviors for its adsorption, Colloids Surf., A: Physicochem Eng. Asp. 469 (2015) 211-223.

27. S. Nethaji, A. Sivasamy, A. B. Mandal, Adsorption isotherms, kinetics and mechanism for the adsorption of cationic and anionic dyes onto carbonaceous particles prepared from Juglans regia shell biomass, Int. J. Environ. Sci. Technol. 10 (2013) 231-242. 